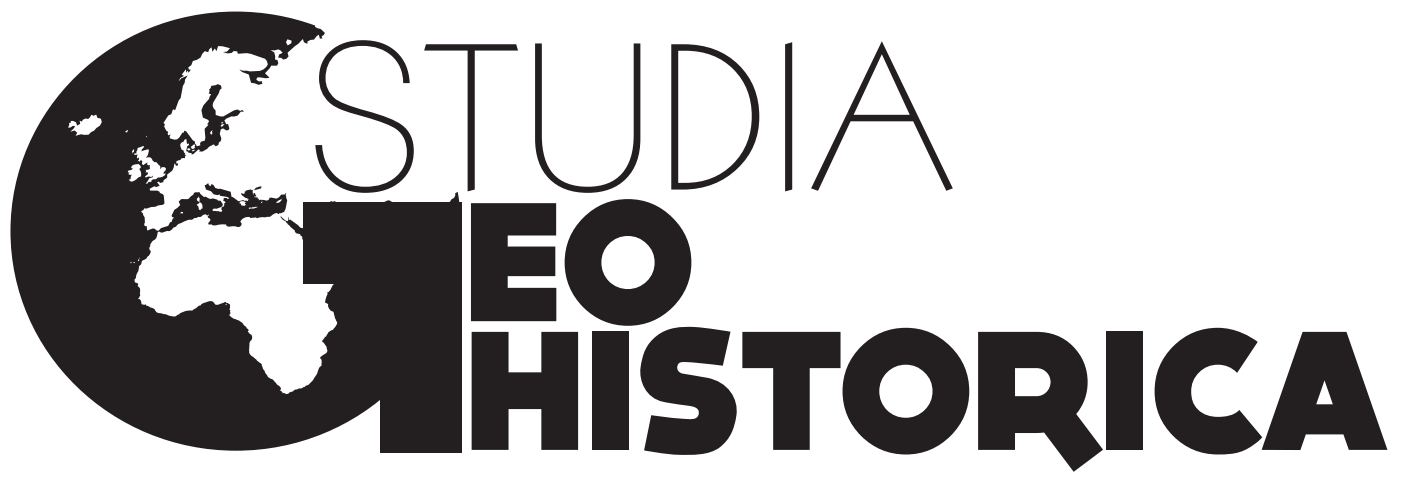

NR 06|2018 ROCZNIK HISTORYCZNO-GEOGRAFICZNY 


\section{Contents}

A note from the editors 5

International Conference of Historical Geographers

Diogo de Carvalho Cabral

Landscape and Letterscape in Early Colonial Brazil 7

Karen M. Morin

Prisoners and Animals: An Historical Carceral Geography ... 28

Humphrey Southall

Spaces, Places, Features and Units: Web-Enabling Historical Geography. 39

\section{Articles and theses}

Agnieszka Latocha, Dominik Nowakowski

Sources and Methods Used in the Reconstruction of Settlement Networks:

An Archaeological and Geographical Perspective on the Example of Silesia

Marek Sobczyński

Polish Geographical Survey of Borders until 1945

\section{Roman Czaja}

Historical Atlas of Polish Towns. Between Source Edition

and the Cartographic Presentation of Research on the History of Towns

\section{Piotr Guzowski}

Economic Geography of Poland in the Period of Growth (14-16th Century)

in the Polish Historical Study

Dzmitry Vitsko

Historical Cartography in Belarus (Studies on the Administrative Division,

Borders and Population of the Grand Duchy of Lithuania)

Henryk Rutkowski

A Few Comments on the Historical Borders in Poland

Bogumił Szady

Historical Cartography of Confessions and Religions in the Polish-Lithuanian

Commonwealth: Between Historical Geography and Spatial History 136 


\section{Tomasz Figlus}

The Past and Present of Historical Morphology of Rural and Urban Forms in Poland

\section{Maryana Dolynska}

Some Principles of Interdisciplinary Investigation

for Recreating the Historical Topography of Urban Spaces

\section{Atlas Fontium}

Atlas Fontium

(Marek Stoń)

Tomasz Panecki, Tomasz Związek, Grzegorz Myrda

The Spatial Database Development for Research on Settlements and Afforestation in Nowy Tomyśl Plain in Early Modern Times

Marek Słoń, Urszula Zachara-Związek (eds.)

The Court Records of Wschowa (1495-1526). Digital Edition

\section{Reviews and discussions}

Deutscher Historischer Städteatlas, Nr. 5: Dortmund, Hrsg. Peter Johanek, Jürgen Lafrenz, Thomas Tippach, Münster 2018 (Michał Stomski) 


\title{
Historical Cartography in Belarus (Studies on the Administrative Division, Borders and Population of the Grand Duchy of Lithuania)
}

\author{
Dzmitry Vitsko
}

Historical geography is a relatively new discipline in Belarus, its age being equal to the age of the independent state of Belarus; it dates back to the early $1990 \mathrm{~s}^{1}$ and the researcher Mikhail Spirydonau. While working at the Institute of History of the Academy of Sciences of Belarus on the monograph entitled 'Subordination of the peasantry in Belarus (15-16 $\left.{ }^{\text {th }} \mathrm{c}.\right)^{\text {', }}$ which saw the light of day in $1993^{2}$, he set out to compile a corpus of data about settlements existing in this period. The result of this work was the map 'Belarus at the end of the $16^{\text {th }} \mathrm{c}$.' (in the scale $1: 1,000,000)$ attached to the aforementioned work ${ }^{3}$. On the back, an academic comment with a list of settlements was printed (there are 1925 on the map within the territory of the present day Belarus). In the comment, it was noted that due to the scale used, the map did not include all settlements known to the author.

In the same place, it was also noted that all the names were provided "by default" in the Ruthenian (Old Belarusian) language. A brief comparison with the

\footnotetext{
1 As the scope of historical geography is very broad, here I will discuss only historical maps published in the period of the last nearly thirty years, which are results of historical-geographical research, as well as those included in historical works of various types. For research on historical geography in the Grand Duchy of Lithuania in various countries, see: G. Błaszczyk, Geografia historyczna Wielkiego Księstwa Litewskiego. Stan i perspektywy badań, Poznań 2007. For research at the Institute of History of the National Academy of Sciences of Belarus, see: B.H. Темушев, Развитие исторической географфии, in: Институт истории Национальной академии наук Беларуси (1929-2009 гг.), рук. А.А. Коваленя et al., Минск 2009, p. 557-561.

2 М.Ф. Спиридонов, Закрепощение крестьянства Беларуси (XV-XVI вв.), Минск 1993.

3 The first version of the map in a smaller scale was printed in 1990: Франциск Скорина и его время: энциклопедический справочник, Минск 1990 (the map 'Belarus in the middle of the $16^{\text {th }}$ c.', scale: 1:2,500,000).
}

sources suggests, however, that they had been adapted to the rules of the contemporary Russian language, in which the monograph was written (this concerns, in particular, ignoring hard - non-palatalized - consonants) ${ }^{4}$. Considering the recipient, the idea of a map in a language which is no longer used is debatable, nevertheless this is what the author insisted on.

Another problem which appeared already at that time and was discussed in the comment was the distinction between types of settlements. This concerns primarily cities and towns. In the Belarusian language (as well as in Russian), contrary to Polish, the word town is not used to mean a small city, it is a different type of settlement. It can be debated whether this was the case in the $16^{\text {th }}$ century, because in the sources quite many settlements are called interchangeably in either way. At the same time, it is clear that by towns mainly trade-craft settlements without city rights were meant. The problem is that in the Grand Duchy many cities (including big ones) also did not have such rights. In this context, selection of the settlement type becomes a problematic issue. The author adopted a solution according to which cities were considered as capitals of provinces and districts as well as "some other settlements of the urban type important for economic, administrative, military and religious reasons". Another issue concerns distinguishing between

\footnotetext{
4 Compare e.g.: Полацкая рэвізія 1552 года, уклаў В. Варонін, Мінск 2011 (map by Viktar Ciemushau and Dzmitry Vitsko 'Polatsk voivodship in the middle of the $16^{\text {th }} c$.').
} 
rural settlements: villages, village complexes inhabited by yeomanry, manor houses, folwarks. Spirydonau abandoned the distinction, marking mainly villages. As we can guess, this was done mainly for the sake of clarity of the map.

The last issue which should be addressed here concerns administrative borders. As later works by Spirydonau suggest, he marked their courses on the map using 'The Listing of Districts and Borders', which, according to his findings, was completed as early as $1565^{6}$. Secondly, we know that delimitations of specific districts were used: Brest, Ashmyany, Pinsk (the privilege with the delimitation was printed out by the researcher) and Navahrudak (the privilege was also printed out $)^{7}$, although in the case of the borders of Ashmyany, these data had not been considered in full. Also various sources from the $16^{\text {th }}$ century had been consulted for data on administrative affiliation of specific settlements. 'The Listing of Districts and Borders' is, however, too general, while in practice the courses of the borders were much more complex, as suggested by materials from the $17^{\text {th }}$ century and newer ones. Secondly, this was not the final decision - in the following years, on some sections, delimitations were still ongoing, to which aim various committees were appointed ${ }^{8}$.

\footnotetext{
5 Определение состава и границ новых поветов Великого княжества Литовского, созданных реформой 1565-1566 годов, а также назначение мест для земских судов в поветах, in: Русская историческая библиотека, т. 30, Юрьев 1914, р. 882-895.

6 М.Ф. Спиридонов, Источники о ресоорме административно-территориального деления Великого княжества Литовского 1565 г. в зарубежных архивах, in: Замежная архіўная беларусіка, рэд. У.М. Міхнюк et al., Мiнск 1998, р. 78.

7 Ibidem, p. 77; M.Ф. Спірыдонаў, Завяршэнне фарміравання Пінскага павета у 1566 г., "Весці НАН Беларусі. Серыя гуманітарных навук", 4, 1998, р. 42-50; Прывілей Жыгімонта Ауггуста на абмежаванне Ноугародскага павета і уивядзенне ў ім земскага суда, Пётркаў, 30 красавіка 1565 г., публ. М.Ф. Спірыдонава, іп: Памяць: гісторыка-дакументальная хроніка Навагрудскага раёна, рэд. М.П. Касцюк et al., Мiнск 1996, p. 102-105.

8 This is demonstrated by Andrei Radaman on the example of the border between the voivodships of Brest and Navahrudak (attempts at separation of the districts of Pinsk and Navahrudak): А.А. Радаман, Да праблемы вызначэння мяжы паміж Новагародскім і Пінскім паветамі Вялікага
}

In fact, at the same time, in exactly the same year (1993), first maps of specific districts at the end of the $16^{\text {th }}$ century were printed, as prepared by Spirydonau in the 'Encyclopaedia of the History of Belarus'. In the total of six volumes of the encyclopaedia, maps of all the districts of the Grand Duchy overlapping in whole or in part with the present-day territory of Belarus were printed (with details marked only for this territory). As opposed to the map discussed above, the type of property was marked (state, aristocracy, Orthodox and Catholic Church) and they had been prepared in colour. In the case of the district of Lida, Catholic and Orthodox churches were marked. In the second volume (1994), a general map 'Belarus at the end of the $16^{\text {th }} \mathrm{c}$.' was printed (without marking the property and with a smaller number of settlements shown $)^{10}$. The publisher of the encyclopaedia, in spite of the opposition of the author of the maps, who cited the principle of historism ${ }^{11}$ (apparently understood too broadly), published all the maps with Belarusian spelling. After the publication of the last volume, the publisher found it necessary to print all the maps included in the encyclopaedia separately in the form of an appendix entitled 'The Atlas of the History of Belarus'12.

княства Літоўскага, Рускага і Жамойцкага ў другой палове XVI ст., in: Памяць стагоддзяу на карце Айчыны: зборнік навуковых прац угонар 70-годдзя Міхаіла Фёдаравіча Спірыдонава, Мінск 2007, р. 73-89. See also work by Mykola Krykun, which discusses, among others, the problem of the northern border of Kiev and its border with the voivodships of Minsk, which later was changed more than once: Н. Крикун, Административно-территориальное устройство Правобережной Украины в XV-XVIII вв. Границы воеводств в свете источников, Киев 1992, р. 118-120. 0bservations of Krykun complement our knowledge regarding the course of the southern borders of the districts of Mazyr and Pinsk, however these are not conclusive data, as they are based primarily on court registers of Ukrainian districts, while materials from the territory of the Grand Duchy in the period after the Union of Lublin show quite a different situation.

Энцыклапедыя гісторыі Беларусі, т. 1-6, Мінск 1993-2003.

10 Ibidem, т. 2, Мінск 1994, р. 394-395.

11 М.Ф. Спиридонов, Беларусь XVI в. на исторических картах, in: Гістарыяграфія гісторыі Беларусі: стан і перспектывы развіцця, рэд. М. Касцюк еt al., Мінск 2000, р. 93.

12 Атлас гісторыі Беларусі ад старажытнасці да нашых дзён (дадатак да 6-томнай “Энцыклапедыі гісторыі Беларусі"), аўтар тэкста Л.І. Языковіч, рэд. Г.Р. Шыкунова, Л.У. Языковіч, Мінск 2004. 
As Viktar Ciemushau aptly notes, this is not an atlas in the proper sense of the word, but just a mechanical collection of maps ${ }^{13}$. However, this was the title under which it was re-published separately from the encyclopaedia ${ }^{14}$. All the maps (districts and the general map) were then re-published many times in other encyclopaedias and reference books ${ }^{15}$. Here, we can notice a tendency of the publishing houses to improve the technical quality, but at the same time to decrease the number of settlements shown.

Several maps by Spirydonau were published in local history books of the 'Memory' series. Noteworthy are those where the number of settlements is bigger than on the maps mentioned above. The first is the 'Navahrudak region at the end of the $16^{\text {th }} \mathrm{c}$.' This is a map of a part of the Navahrudak district of the Grand Duchy of Lithuania, limited to the present-day area of Navahrudak. The number of settlements is far greater here than in the map of the Navahrudak district in the encyclopaedia; it also comprises churches, broken down into Catholic, Orthodox and Protestant. At the bottom, it has been noted that the map was developed on the basis of the "Chronicles of settlements of the Navahrudak region', i.e. history of individual settlements located towards the end of the volume prepared also by Spirydonau (unfortunately, this edition did not include citations) ${ }^{16}$. The second map is the 'Minsk region at the end of the $16^{\text {th }}$ c.' Catholic and Orthodox churches are not marked, but settlements (on the territory of the present-day region of Minsk and some neighbouring regions)

\footnotetext{
13 В.М. Цемушаў, "Вялікі гістарычны атлас Беларусі" у крывым люстэрку рэцэнзіі (Адказ на рэцэнзію Алега Латышонка і Генадзя Семянчука), "Arche", 6, 2010, p. 331.

14 Атлас гісторыі Беларусі ад старажытнасці да нашых дзён, Мінск 2006.

15 For a list of these maps, see: М.Ф. Спиридонов, Беларусь, р. 94; Памяць стагоддзяу, р. 410-429.

16 Памяць: гісторыка-дакументальная хроніка Навагрудскага раёна, p. 118-119 (map), 526-556 (settlements).
}

have been divided according to the property type ${ }^{17}$.

Mikhail Spirydonau created also two maps of large estates - latifundia. The first is a map of the estates of Wasil Ciszkiewicz (Tyszkiewicz) and his sons in $1570^{18}$, which features an appendix (a list of the estates), but, unfortunately, is illegible (printed in insufficient scale). The second one is a map of the estates of Jan Hlebowicz and his sisters in 1583, appended to the work on Zaslawye ${ }^{19}$.

Unfortunately, Spirydonau did not manage to publish all the findings he had collected in the course of his research and presented on maps. Only individual maps were published with lists of settlements prepared with reference to some sources, specifically army censuses of the Grand Duchy of Lithuania and the books of the Lithuanian Metrica ${ }^{20}$. These works can be used for further studies on the administrative division and population of the Grand Duchy of Lithuania. Still, the significance of the works of Spirydonau as the father of Belarussian historical geography is grand. It was him who has laid the foundation for further development of the discipline, presenting his own method of creating maps and commented settlement lists. Historical-geographical knowl-

17 Памяць: гісторыка-дакументальная хроніка Мінскага раёна, рэд Г.П. Пашкоў еt al., Мінск 1998, р. 51.

18 М.Ф. Спірыдонаў, Першая ардынацыя ў Беларусі, "Гістарычна-археалагічны зборнік", 8, 1996, p. 198-216 (map on p. 211).

19 М.Ф. Спиридонов, Заславль в ХV/ в., Минск 1998 (map on p. 18-19).

20 See the commented index of the settlements and maps 'Settlements mentioned in the army census of the Grand Duchy of Lithuania 1528', and 'Settlements in Podlaskie Voivodship mentioned in the army census of the Grand Duchy of Lithuania 1528' appended to the edition of this census (Перапіс войска Вялікага княства Літоускага 1528 года, рэд. А.І. Груша, М.Ф. Спірыдонаў, М.А. Вайтовіч, Мінск 2003) and the commented dictionary of the settlements of the Minsk district mentioned in the census of 1567 with a map of these settlements prepared by Viktar Ciemushau on the basis of Mikhail Spirydonau's data (М.Ф. Спиридонов, Населенные пункты Менского повета в 1567 г., in: Актуальныя пытанні вывучэння і выдання Метрыкі Вялікага Княства Літоускага, рэд. С.П. Віцязь et al., Мінск 2005, р. 159-190). See also the map 'Settlements of Belarus mentioned in the book 225 of the Metrica of the Grand Duchy of Lithuania' (М.Ф. Спиридонов, Метрика Великого княжества Литовского как источник по истории поселений, in: Lietuvos Metrika: 1991-1996 mety tyrinéjimai, sud. Z. Kiaupa, A. Urbanavičius, Vinius 1998, p. 115-133). 
edge about the Grand Duchy of Lithuania after the Union of Lublin is nowadays largely based on his maps.

Returning to the 'Encyclopaedia of the History of Belarus', one should also mention maps of another pioneer of historical geography, Viachaslau Nasievich. Firstly, the entry 'Grand Duchy of Lithuania' was supplemented with two maps showing the establishment and the territorial developments of this state: 'Grand Duchy of Lithuania in the $13^{\text {th }}$-first half of the $14^{\text {th }} c$.' and 'Grand Duchy of Lithuania in the $14-15^{\text {th }} \mathrm{c}$.' The former presents the process of establishment of the Grand Duchy of Lithuania according to his theory, the latter - the period of its greatest territorial advancement, when it spread "from one sea to another". Secondly, several maps by this scholar show specific starosties (estates) of the Grand Duchy of Lithuania ${ }^{21}$, which is related to his interest in local history.

Nasievich also wrote for the book series 'Memory' and some of his chapters were supplemented with maps. These maps show (with breakdown into estates) the territories of the present-day regions of: Horki - in the middle of the $17^{\text {th }}$ century ${ }^{22}$, Luninyets - at the end of the $16^{\text {th }}$ (with Orthodox churches marked) and at the end of the $17^{\text {th }}$ century (with Orthodox and Uniate as well as Catholic churches marked together with the number of houses in each settlement ${ }^{23}$, Krup$\mathrm{ki}$ - in the second half of the $16^{\text {th }}$-first half of the $17^{\text {th }}$ and in the first half of the $18^{\text {th }}$ century ${ }^{24}$, Kruhlaye in the $16-17^{\text {th }}$ and at the end of the $18^{\text {th }}$-beginning of

21 I will not list all of them, all the more so because Grzegorz Błaszczyk has already done it: G. Błaszczyk, Geografia, p. 93.

22 В.Л. Насевіч, 3 сівой даўніны, іп: Памяць: гісторыка-дакументальная хроніка Горацкага раёна, рэд. А.А. Крывянкоу еt аl., Мінск 1996, р. $26-41$.

23 В.Л. Насевіч, У складзе Вялікага княства Літоускага, in: Памяць: гісторыка-дакументальная хроніка Лунінецкага раёна, уклад. Т.В. Канапацкая, Мінск 1995, р. 29-45. It was noted that the chapter was prepared using materials of Mikhail Spirydonau; most likely this refers also to the first of the two maps.

24 Idem, У складзе Полацкага княства. У складзе Вялікага княства Літоускага, in: Памяць: гісторыка-дакументальная хроніка Крупскага раёна, склад. і рэд. Д.М. Хомчанка, Мінск 1999, р. 37-64. the $19^{\text {th }}$ century (temples marked regardless of denomination and the number of houses in each settlement in the last quarter of the $18^{\text {th }}$ century $)^{25}$, Dokshytsy and others. These chapters and the accompanying maps have citations, so in this respect they can be considered as academic. Apart from these works, this scholar made attempts to complete a scientific reconstruction of the borders of some feudal principalities (estates), specifically of the Principality of Drutsk in the $14-15^{\text {th }}$ century ${ }^{26}$, Principality of Lukoml at the beginning of the $15^{\text {th }}$ century $y^{27}$ and Minsk in the $12-15^{\text {th }}$ century $^{28}$.

Another important project completed in 2002 in collaboration with historians is the 'National Atlas of Belarus'29. The chapter 'History' of the atlas contains a variety of new maps, including maps devoted to the Grand Duchy of Lithuania. To us, of interest are mainly the maps: 'Establishment of the Grand Duchy of Lithuania, Ruthenia and Samogitia, second half of the $13^{\text {th }}-14^{\text {th }}$ c.' and 'Grand Duchy of Lithuania in the $15^{\text {th }}$-first half of the $16^{\text {th }}$ c.' by Viachaslau Nasievich (in the scale 1:5,500,000), 'Belarus in the second half of the $16^{\text {th }}$ c.' by Mikhail Spirydonau (in the scale 1:1,500,000) and 'Belarus in the second half of the $18^{\text {th }} \mathrm{c}$.' by Yauhien Anishchanka (scale 1:1,500,000) ${ }^{30}$. The

25 Idem, Феадальныя маёнткі і іх уладальнікі, in: Памяць: гісторыка-дакументальная хроніка Круглянскага раёна, рэд. Г.П. Пашкоў et al., Мінск 1996, р. 92-106, 117-119.

26 В.Л. Насевіч, Род князёў Друцкіх у гісторыі Вялікага Княства Літоўскага (XIV-XVI стст.), in: Старонкі гісторыі Беларусі, рэд.: М.П. Касцюк et al., Мiнск 1992, p. 83-104. Here two diagram maps were published: of the Principality of Drutsk and surroundings in the $14-15^{\text {th }}$ century and a more detailed map of the estates of Drutsk (untitled), mistakenly related to the preceding article.

27 Idem, Лукомль i Лукомльская воласць, "Гістарычна-археалагічны зборнік", 4, 1994, р. 161-186.

28 Idem, Менскае княства і воласць у XII-XV ст., "Беларуская даўніна", 2, 2015, р. 50-63.

29 Нацыянальны атлас Беларусі, рэд. У.М. Мясніковіч et al., Мінск 2002. Contrary to what Grzegorz Błaszczyk stated (G. Błaszczyk, Geografia, p. 115, footnote 939), the authorship of the maps in the 'National Atlas of Belarus' was marked, the names were given at the beginning.

30 See a critical review by Viktar Ciemushau on this chapter of the atlas: B.М. Цемушаў, Праблемы развіцця гістарычнай геаграфіi Беларусі, "Беларускі гістарычны агляд", 10 (1-2), 2003, р. 228-255. 
second map by Nasievich presents the state with internal division into viceroyalties, autonomous lands-viceroyalties and appanage principalities. The map by Spirydonau is his old map, but reworked on an entirely new technological level and with division of estates according to the property type (which earlier was the case only with district maps) and, again, in the Ruthenian language. It appears, however, that this map of administrative divisions and settlements has been unnecessarily combined with the Livonian War and Cossack incursions from the end of the $16^{\text {th }}$ century (and the arrows showing the incursions have also been selected rather poorly). The map by Anishchanka shows also the division into districts and the property type. The administrative division, however, has not been shown clearly, as the voivodships are not differentiated from districts (marked with borders of the same type). Secondly, the course of borders in many places is doubtful. Most probably, the author attempted to "join" the estates within the borders of some districts so that their parts are not shown within the borders of the neighbouring ones. Such an approach, however, is not justified. For example, the border between the voivodships of Navahrudak and Minsk on the Neman is older than the borders of the estates on its banks and corrections thereto are unnecessary. In general, the problem requires close scrutiny, because in each specific case it could be different: there existed divided estates, but theoretically it could happen that the borders differed from those established at the time of the reform in the $16^{\text {th }}$ century. It is also necessary to establish the borders, whenever possible, of "cross-border" estates, which in turn allow to accurately establish the administrative borders. Moreover, it seems unlikely that throughout the whole second half of the $18^{\text {th }}$ century the status of a city was enjoyed only by capitals of districts, as shown on the map (with the exception of, it seems, only Mahilyow, but not settlements as large as, for example, Slutsk, which was counted among towns). As a result, the level of urbanisation in the Grand Duchy of Lithuania on the map sharply contrasts with the situation in neighbouring Poland (and Russia), where many more cities are marked.

In 2005-2006, one more encyclopaedia written in Belarusian saw the light of day - 'The Grand Duchy of Lithuania' (in 2 volumes; new edition in 3 volumes in 2007-2010; hereinafter we use this last edition). Many entries and much content were copied from the 'Encyclopaedia of the History of Belarus'; the same happened to the maps. All maps by Spirydonau (districts and general) and Nasievich (starosties and a slightly modified map of the Grand Duchy of Lithuania in the $13^{\text {th }}$-first half of the $14^{\text {th }}$ century) were carried over. The map 'Grand Duchy of Lithuania in the middle of the $18^{\text {th }}$ c.' by Anishchanka ${ }^{31}$ is, in fact, a simplified version of his map from the 'National Atlas of Belarus'. Also, new maps of the economies (estates serving directly the king) of Brest, Mahilyow, Hrodna and Vitsyebsk by Anishchanka ${ }^{32}$ were included in addition to 'Lithuania in the middle of the $13^{\text {th }}$ c.' by Nasievich (with break-down into Lithuanian territories on the basis of archaeological cultures $)^{33}$ and Ciemushau ('Grand Duchy of Lithuania in 13451430 '34, 'Changes to the eastern border of the Grand Duchy of Lithuania at the end of the $15^{\text {th }}$-the first $1 / 3$ of the $16^{\text {th }}$ c. $^{\prime 35}$, 'Upper Oka Principalities at the end of the $13^{\text {th }}$-beginnings of the $16^{\text {th }}$ c. $^{\prime 36}$, 'Prin-

\footnotetext{
31 Вялікае Княства Літоусскае: Энцыклапедыя, т. 1, рэд. Г.П. Пашкоў et al., Мiнск 2007, p. 28-29.

32 See individual entries.

33 Вялікае Княства Літоўскае: Энцыклапедыя, т. 2, рэд. Г.П. Пашкоў еt al., Мінск 2007, р. 203.

34 Ibidem, T. 1, p. 11.

35 Ibidem, p. 369.

36 Ibidem, p. 477.
} 
cipality of Volkona' ${ }^{37}$, 'District of Homyel in the Grand Duchy of Moscow in 1500$\left.1537^{\prime 38}\right)$. The article 'Neuburg family estates' was supplemented with the map 'Neuburg family estates in the second half of the $17^{\text {th }}$-first half of the $18^{\text {th }}$ c.' by Andrei Matsuk and Ciemushau ${ }^{39}$. This map in a larger scale was appended to the monograph by Matsuk 'Struggles of magnate parties in the Grand Duchy of Lithuania (1711-1763) ${ }^{\prime 40}$.

Another important joint project with participation of quite a large group of researchers from various institutions is the 'Great Historical Atlas of Belarus'. The atlas is scheduled for release in four volumes, to date three have seen the light of day. The period of the Grand Duchy of Lithuania has been split in this edition between the first and second volume ${ }^{41}$. The editor-in-chief of the atlas is Nasievich, who (together with Ciemushau) is also the author of basic maps located in the first volume: 'Establishment of the Grand Duchy of Lithuania, 1245-1315', 'Territorial developments of the Grand Duchy of Lithuania in the times of Gediminas and Algirdas, 1315-1377', 'The biggest territorial advancements of the Grand Duchy of Lithuania in the times of Vytautas, 1392-1430' as well as his 'Belarusian lands in the Grand Duchy of Lituania, 1440-1470'. It shows land estates with break-down into state, Catholic and Orthodox church and privately-owned (with the last category split according to the

\footnotetext{
37 Ibidem, т. 3, рэд. Т.У. Бялова et al., Мінск 2010, р. 99.

38 Ibidem, p. 184.

39 Ibidem, т. 2, р. 365.

40 А. Мацук, Барацьба магнацкіх груповак у ВКЛ (1717-1763), Мінск 2014.

41 Вялікі гістарычны атлас Беларусі, рэд. В.Л. Насевіч, т. 1, Мінск 2009; ibidem, т. 2, Мінск 2013. Apart from the "Great" one, in 2008 in Warsaw also the first volume of the 'Historical Atlas of Belarus' was published: Гістарычны атлас Беларусі, рэд. М. Спірыдонаў, В. Мікалаевіч, П. Казанецкі, т. 1: Беларусь ад старажытных часоў да канца XVIII ст., Варшава-Miнск 2008. Because its contents are similar (the team of authors is almost the same), but the 'Great Historical Atlas of Belarus' is much bigger, here I ignore the former and refer readers to the review by Viktar Ciemushau: B.М. Цемушаў, Гістарычныя атласы і стан развіцця сучаснай гістарычнай геаграфіі у Беларусі, "Гісторыка-археалагічны зборнік", 25, 2010, p. 200-203.
}

origin and denomination of the owners). The history of the borders is presented on the map by Ciemushau 'Relations of the Grand Duchy of Lithuania with the Grand Duchy of Moscow and the Krimean Chanate, 1487-1537'. It also features maps showing the distribution of municipal self-governments and basic denominations (the network of parishes and monasteries; the maps of the distribution of Catholic and Orthodox churches believers were prepared by Rascislau Baravy).

The general map 'Belarusian lands in the $16^{\text {th }}$ c.' prepared by Nasievich and Spirydonau consists of 51 sheets in the scale 1:300,000. The introduction states that the basis for the creation thereof were data of Spirydonau, both printed and from the researcher's card file (currently stored at the Institute of History of the National Academy of Sciences of Belarus - D.V.) in addition to the database of the research project 'Data corpus from historical geography of Belarus $10^{\text {th }}-16^{\text {th }}$ c.' carried out under the supervision of Spirydonau in 1993-1995. As regards the borders of estates, here the basis were the results of research of Nasievich (partially printed, see above). Within the territory of Belarus, 4306 settlements are marked, i.e. two times as many as on the well-known map of Spirydonau ${ }^{42}$. The following are also marked: type of property, presence of self-government in cities (with the date of issuing the privilege) and Catholic and Orthodox churches (with the year of the first mention).

Firstly, it can be said that the majority of estate borders are arbitrary and have been marked approximately, which is best seen thanks to the large scale. In many cases the sources make it possible to establish their factual course, including using the retrospection method. Obviously, this huge task cannot be completed within the

\footnotetext{
42 В.Л. Насевіч, Беларускія землі у XVI ст., in: Вялікі гістарычны атлас Беларусі, т. 1, р. 96-97. 
atlas. The same is true for the borders of voivodships and districts, which has already been mentioned in the case of Spirydonau's map. Since its publication, the situation has not changed much, unfortunately. Here, the borders have been shown differently than in Spirydonau's map, but given the lack of scientific research, we can only guess the reasons for the discrepancies. Secondly, the map marks manors houses and folwarks as villages. It seems that distinguishing between these types of rural settlements would be worthwhile.

In the historical-geographical index of this map, there is information about the names of settlements being written in the contemporary Belarusian language, in the language of the sources (Ruthenian), territorial affiliation with some estates, the owner as of 1567, the first mention, administrative affiliation back then and now. The lack of citations makes it impossible to consider all this great work as strictly scientific, because only part of the data used had been introduced earlier; the publication is oriented rather towards popular science. The same is true for the first mentions of temples and presence of self-government not knowing where these pieces of information come from, it is difficult to analyse the contents of the edition.

The publication of the first volume of the atlas generated a heated debate. Aleh Latyshonak and Hienadz Siemianchuk claimed that the atlas did not deserve its name and the money had in fact been wasted. Critical remarks concerned primarily other parts of the first volume than the Grand Duchy of Lithuania. As regards the latter, the reviewers' objections were caused primarily by the fact that the population and network of parishes of Podlachia have been presented poorly on the general map and maps showing denominations ${ }^{43}$. This remark is

43 А. Латышонак, Г. Семянчук, Марныя высілкі акадэмічных гісторыкаў, "Arche", 6, 2010, p. 298-322. right, because to date Podlachia has been thoroughly researched; this precisely is the case where works of other historians should have been consulted. Be that as it may, a large portion of these remarks were debatable, which was used by the authors of the maps (Nasievich and Ciemushau) in their responses. In general, the review was rather impolite, therefore the discussion did not go well; only Ciemushau attempts in his response to draw attention to genuine problems with preparation of the maps and the conditions of work on the atlas (including interference with original maps of the authors ${ }^{44}$.

The second volume of the 'Great Historical Atlas of Belarus' starts with a map by Spirydonau 'Grand Duchy of Lithuania in 1569 after the creation of PolishLithuanian Commonwealth', edited by Ciemushau. This is an old map by Spirydonau with some borders corrected (e.g. voivodships around Bykhaw). It is not clear, however, why it differs so much from the general map from the first volume (for example, western and southern borders of the Vitsebsk district, eastern borders of the district of Hrodna, northern-eastern borders of the district of Rechytsa, affiliation of the Valozhynskaya and Lipiczanskaya forests, and others). Then, follows a selection of maps on wars and uprisings in the $16^{\text {th }}-18^{\text {th }}$ century. The administrative borders change slightly depending on the author; it is visible, for instance, on the maps by Anishchanka ('Grand Duchy of Lithuania on the eve of the partitions of the Polish-Lithuanian Commonwealth, 1740s-1760s', 'Belarusian Lands in 17721793'). Here, again, there are no differences with respect to the borders of voivodships and districts. From among other maps included in the volume, we can mention 'Demographic losses of the districts of the Grand Duchy of Lithuania

44 В.Л. Насевіч, Некалькіразважанняў з нагоды рэцэнзіі Алега Латышонка і Генадзя Семянчука, "Arche", 6, 2010, p. 323-329; B.М. Цемушаў, "Вялікі гістарычны атлас Беларусі", р. 330-343 
between 1650 and 1667' (prepared by Viachaslau Nasievich based on the data of Józef Morzy), 'Municipal self-government in the Grand Duchy of Lithuania in the second half of the $16^{\text {th }}$-first half of the $18^{\text {th }}$ c.' (prepared on the basis of the entry 'Magdeburg rights' in the encyclopaedia 'Grand Duchy of Lithuania', so these data are incomplete), 'Density of population of the districts of the Grand Duchy of Lithuania in the third quarter of the $18^{\text {th }}$ c.' (the author, Nasievich, refers to his own methodology $)^{45}$. Maps on denomination show monasteries of various denominations (Catholic with breakdown into orders), schools, seminars; only Protestant churches have been shown. Most likely this is related to the fact that all other temples have been marked on the general map.

The general map 'Belarusian lands at the end of the $18^{\text {th }}$ c.', created by Nasievich and Anishchanka, shows 17,348 settlements on the territory of the presentday Belarus. This presentation is not exhaustive (slightly less than half of the total number, in fact) - even such a large scale $(1: 300,000)$ did not allow for presentation of everything. The map is based on various data, mainly from archives (audits of economies and starosties, house tax tariffs, descriptions of parishes, property inventories, materials from General survey (Rus. Генеральноемежевание) and others.

In the preparation of the atlas, the issue of differentiation between cities and towns appeared once again, therefore this topic was touched upon twice in articles explaining the maps. The publisher of the atlas decided to stick with their own criteria thereof, which consisted in a settlement meeting at least three out of six conditions: being the capital of an administrative unit, a centre of a large estate, having self-government formed according

45 В.Л. Насевіч, Сацыяльна-эканамічнае развіццё, in: Вялікі гістарычны атлас Беларусі, т. 2, р. 42. to the Magdeburg rights, having city-like fortifications, presence of parishes of at least three Christian denominations and no fewer than one monastery ${ }^{46}$. These are extremely complex criteria, not used in the practice at that time. It reflects reluctance to accept the legal approach and the fact of a settlement having city rights as the criterion decisive of the city status; instead, a quantitative approach characteristic of the Soviet Union can be witnessed. An attempt has been made to distinguish between rural settlements (settlements of yeomanry were presented separately) but combining villages with folwarks is, in my opinion, a poor solution. One positive fact is that the publisher found it necessary to stick with the historical forms of the settlement names, disregarding foreign influence and the current situation with names in the Belarusian language.

I do not intend to write a review of all historical-geographical publications, but to offer a very general overview of such publications featuring historical maps. Therefore, I shall also discuss the works of two scholars whose main area of activity are geographical-historical issues.

One of them is Viktar Ciemushau, who was the first scholar to create maps entirely on his own on the basis of the newest necessary software. His research interests concerned primarily the Grand Duchy of Moscow. Then, while working at the Institute of History of the Academy of Sciences of Belarus, he was concerned with the history of the Moscow-Lithuanian border and his second major interest was historical geography of the territory of Belarus before the Union of Lublin. In 2009, his book about the land of Homyel $^{47}$ was published; then he planned to

\footnotetext{
46 Ibidem; Я. Анішчанка, В.Л. Насевіч, Беларускія землі у канцы XVIII cт., in: Вялікі гістарычны атлас Беларусі, т. 2, p. 68-69.

47 B.H. Темушев, Гомельская земля в конце XV-первой половине XVI в. Территориальные трансформации в пограничном регионе, Москва 2009. What is meant is the Homyel estate of the Grand Duchy of Lithuania (end of $15^{\text {th }}$ century), later a district of Moscow (beginning of $16^{\text {th }}$ century) and a starosty of Lithuania in the middle of the $16^{\text {th }}$ century. On the side,
} 
deal with the estates of the Dnieper region, around the Dvina and then to move on to the central territories of the presentday Belarus ${ }^{48}$. Unfortunately, these plans were thwarted by the untimely death of the scholar in 2011 (he passed away after a severe illness at the age of 36). Already after his death, in 2013, in Russia, his monograph devoted to the war between Moscow and Lithuania of 1486-1494 was published (chronology suggested and justified by the scholar) ${ }^{49}$. A year later, his monograph was published in Belarusian, featuring both research on the wars and border between Moscow and Lithuania in the middle of the $14^{\text {th }}$-middle of the $16^{\text {th }}$ century, and a new edition of the older work on the land of Homyel ${ }^{50}$.

changes to this section of the Moscow-Lithuanian border were considered. The book features colour maps 'Moscow-Lithuanian border at the end of the $15^{\text {th }}$-first half of the $16^{\text {th }} \mathrm{c}$.' and 'Land of Homyel at the end of the $15^{\text {th }}$-first half of the $16^{\text {th }} c$.' as well as black-and-white: 'Territory of the starosty of Homyel in the middle of the $16^{\text {th }}$ C., 'Territory of the district of Homyel in 1500-1535', 'Territory of the Homyel estate on the left

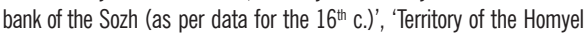
estate on the right bank of the Sozh (as per the data for the first quarter of the $16^{\text {th }} \mathrm{c}$.)', 'Eastern borderlands of the Grand Duchy of Lithuania at the end of the $15^{\text {th}}$-beginning of the $16^{\text {th }}$ c.', 'Settlement in the Homyel estate in the $15^{\text {th }} \mathrm{c}$.', 'Upper Oka Principalities in the $15^{\text {th }}$-beginning of the $16^{\text {th }}$ c.', 'The Principality of Vyazma in the $15^{\text {th }}$ c.', 'The Rzhev section of the Lithuanian-Moscow border in the second half of the $15^{\text {th }}$ c.' The work is supplemented with a commented geographical index 'Settlement of the land of Homyel in the $15^{\text {th }}$ first half of the $16^{\text {th }}$ c.'

48 B.H. Темушев, Автобиографиия (http://www.hist-geo.net/index.php?blog $=1 \&$ paged $=9$, access: April 4, 2018).

49 Idem, Первая московско-литовская пограничная война, 1486-1494, Москва 2013.

50 В.М. Цемушаў, На ўсходняй мяжы Вялікага княства Літоўскага (сярэдзіна XIV-першая палова XVI ст.), Смаленск 2014. Here the following maps were included: 'Lithanian-Moscow border in the second half of the $15^{\text {th }}$-first $1 / 3$ of the $16^{\text {th }} c$.', 'District of Toropets at the end of the $15^{\text {th }}$ c.', 'Land of Rzhev in the second half of the $14^{\text {th }}$ c.', 'Rzhev section of the Lithuanian-Moscow border in the second half of the $15^{\text {th }} \mathrm{c}$.', 'Principality of Tver and its neighbours in the $13-15^{\text {th }} \mathrm{c}$.', 'Lithuanian-Tver border in the second half of the $14^{\text {th }}$-beginning of the $16^{\text {th }}$ c.', 'Principality of Fomin Gorodok-Berezuysk in the Lithuanian-Moscow-Tver borderland at the end of the $14^{\text {th }}-15^{\text {th }}$ c.', 'Principality of Vyazma in the $15^{\text {th }} c$.', 'Principality of Tarusa and its territories in the second half of the $14^{\text {th }}-15^{\text {th }}$ c.', 'Land of Mozhaysk in the $14^{\text {th }}-15^{\text {th }}$ c.', 'Ugra region in the $15^{\text {th }}$ c.', 'Upper Oka Principalities at the end of the $13^{\text {th }}$-beginning of the $16^{\text {th }} c$.' ' 'The estate of Lyubech in the first half of the $16^{\text {th }} \mathrm{c}$.' 'Disputed sections of the Lithuanian-Moscow border in the first half of the $16^{\text {th }}$ c.', 'Algirdas's conquests of Moscow, 1368-1372', 'Lithuanian-Moscow war, 1406-1408', 'Battle on the Sukhodrev, winter 1445', 'Moscow-Lithuanian war, 1486-1494', 'Moscow-Lithuanian war, 1500-1503', 'Uprising of Michael Glinski and Moscow-Lithuanian war, 1507-1508', 'Moscow-Lithuanian war, 1512
In 2016, this work was published in Rus$\operatorname{sian}^{51}$. In addition, quite many articles on historical-geographical topics were published, mainly concerning the history of the border, and some of them were supplemented with maps created by the scholar $^{52}$. Apart from that, Ciemushau created many maps for other scholars ${ }^{53}$. It is not possible to list all of them here.

1522', 'Lithuanian-Moscow war, 1534-1537', 'Situation of the borderland in the Ugra region in the first $1 / 3$ of the $17^{\text {th }} \mathrm{c}$.', 'Estate of Dmitrovets in the second half of the $17^{\text {th }} \mathrm{c}$.' and seven maps of the Homyel land (see above).

51 В.Н. Темушев, На восточной границе Великого княжества Литовского. Середина XIV-первая половина XVI в., Тула 2016.

52 Idem, Кричевский участок литовско-московской границы в XVI в., in: Studia historica Europae Orientalis = Исследования по истории Восточной Европы, вып. 3, Минск 2010, p. 135-165; idem, Спорные участки литовско-московской границы XVI в., in: Матэрыялы па археалогіі Беларусі, вып. 20, Мінск 2011, р. 112-118; idem, Феномен московско-литовского порубежья XV века, in: Вялікае княства Літоусккае і яго суседзі ў XIV-XV стст., уклад. А.І. Груша, С.В. Марозава, Мінск 2011, р. 199-206; В.Н. Темушев, К вопросу о московско-литовской границе в XV в. (Волости Чагоща и Болонеск), in: Матэрыялы па археалогіi Беларусі, вып. 15, Мінск 2008, р. 186-193; idem, Сведения о московско-литовском пограничье в посольских книгах времени Ивана III, in: Труды кафедры истории России с древнейших времен до ХХ века, отв. ред. А.Ю. Дворниченко, Санкт-Петербург 2006, р. 294-306; В.М. Цемушаў, "Вайна падчас міру". Першая памежная вайна ВКЛ з Масквою (1486-1494), "Беларускі гістарычны агляд", 15 (1-2), 2008, p. 5-48; В.Н. Темушев, Западная граница Великого княжества Московского к 1380 r., in: Куликовская битва в истории России, ред. А.Н. Наумов, Тула 2006, р. 82-109; В.М. Цемушаў, Мажайская зямля: яе тэрыторыя і межы, "Беларускі гістарычны часопіс", 1, 2002, р. 23-28; В.Н. Темушев, Пограничные города Великого княжества Литовского: Дмитровец в XV в., in: Studia historica Europae Orientalis = Исследования по истории Восточной Европы, вып. 2, Минск 2009, р. 44-122; В.М. Цемушаў, Тросненская бітва і паўднёва-заходняя мяжа Вялікага Княства Маскоускага у 1368 г., "Беларускі гістарычны агляд", 13 (2), 2006, p. 135-176; В.Н. Темушев, Представления о территории и границах Верхнеокских княжеств в работах исследователей, in: Верхнее Подонье: Природа. Археология. История, т. 2: История, ред. А.Н. Наумов, Тула 2007, р. 257-277; idem, Литовско-тверская граница (вторая половина XIV-начало XVI в.), "Вестник ТвГУ. Сер. История", 4, 2007, p. 87-97; idem, Ржевский участок литовско-московской границы в конце XIV-начале XVI в., in: Матэрыялы па археалогіі Беларусі, вып. 14, Мінск 2007, р. 241-250.

53 Among them the maps: 'Principality of Mstsislaw in the period of Lengvenids' (В.А. Варонін, Князь Юрай Лынгвеневіч Мсціслаусккі: гістарычны партрэт, Мінск 2010); 'Cities founded on the Vitsebsk rights in the second half of the $16^{\text {th }} c$.' and 'Estates of Krupienich family in the $16^{\text {th }}$ с.' (М.Д. Макараў, Ад пасада да магдэбургіi: прававое становішча насельніцтва местаў Беларускага Падзвіння ў XIV-першай палове XVII ст., Мiнск 2008); 'Northern part of the Polatsk voivodship at the end of the $16^{\text {th }}$ c.' (В.А. Варонін, Рэестр путных баяр Полацкага ваяводства 1585 года, Мінск 2009); 'Districts of Brest, Kamyenyets, Kobryn at the end of the $15^{\text {th }}$-first half of the $16^{\text {th }}$ c.' (В. Мянжынскі, А. Дзярновіч, Шляхта, іншыя землеўласнікі і землеўладальнікі ды іхныя зямельныя ўладанні у Берасцейскім, Камянецкім і Кобрынскім паветах у другой палове XV-першай палове XVI ст. (паводле Кнігаў 
Anyway, it will be difficult for Belarusian and other historians concerned with the Grand Duchy of Lithuania to achieve, in the near future, the quality of research of the history of the border and borderland and the technical level of historical maps presented by Ciemushau.

One of his maps, which he did not manage to finish on his own, was a map of the Polask voivodship in the middle of the $16^{\text {th }}$ century as an appendix to the new edition of the revision of this voivodship in 1552 together with the commented geographical index (the system for identification of settlements developed by Ciemushau deserves particular attention). As a result of finishing the work started by this author, it was possible to locate many more settlements than on the maps of the 'Great Historical Atlas' and older and it was done only based on the aforementioned revision with information from sources from the first half of the $16^{\text {th }}$ century added ${ }^{54}$.

The second prominent researcher of historical geography among Belarusian historians is Andrei Miacielski, the author of the great work 'The Principality and Voivodship of Mstsislaw in the 12$18^{\text {th }}$ c. ${ }^{55}$ In his monograph on the Principality of Mstsislaw, the author traces back the history of the principality from its creation as an appanage principality until the period after the transformation into a voivodship and existence in such a state until the first partition of the Polish-Lithuanian Commonwealth and its annexation by Russia. Miacielski devotes his attention primarily to the territorial developments of the Principality of Mstsislaw, delineation of its borders and

№ 12-33 Метрыкі ВКЛ), in: Metriciana, т. 3, Мінск 2004, р. 57-196). I do not mention here work by Russian historians with whom Viktar Ciemushau closely cooperated.

54 Полацкая рэвізія (map by Viktar Ciemushau and Dzmitry Vitsko 'The Polatsk voivodship in the middle of the $16^{\text {th }} c$.' and the commented geographical index on p. 207-213).

55 А.А. Мяцельскі, Мсціслаўскае княства і ваяводства у XII-XVIII стст., Мінск 2010 (2 выд., Мінск 2014). then investigation of borders, settlement and population of the Mstsislaw voivodship. The author studies population of the principality and the voivodship in general, stopping at the levels of cities, towns and villages. In particular, it should be noted that he had researched religious life of the principality and the voivodship and studied the situation of Orthodox, Catholic, Uniate churches as well as the spread of Judaism. The monograph contains quite a lot of maps ${ }^{56}$, which, however, have not been prepared according to the current technical quality standard $s^{57}$. Nevertheless, all the maps are legible, therefore this is not a major fault. The work has been written on the basis of a huge number of sources, primarily from archives, including cartographic sources. It contains numerous tables which present the collected data on the first mentions or foundation of settlements, their locations and the relevant citations (the same is the case for all temples $)^{58}$. Here, there are many more settlements than on the previous maps of Belarusian lands in the $16^{\text {th }}$ century. In this respect, this is a model work and it can

\footnotetext{
56 They are black-and-white maps: 'Principality of Mstsislaw in the $14^{\text {th }}$-beginning of the $15^{\text {th }}$ c.', 'Principality of Mstsislaw in the $15^{\text {th }}$ c.', 'Principality of Mstsislaw at the beginning of the $16^{\text {th }}$ c.', 'Settlements of the Principality of Mstsislaw in the $15^{\text {th }}$ c.', 'Settlements of the Principality of Mstsislaw in the $16^{\text {th }} \mathrm{c}$.', 'Settlements of the Voivodship of Mstsislaw in the $17^{\text {th }}$ c.', 'Settlements of the Voivodship of Mstsislaw in the $18^{\text {th }} \mathrm{c}$.', 'Cities and towns of the Voivodship of Mstsislaw in the $18^{\text {th }} \mathrm{c}$.', 'Temples in the $15-16^{\text {th }} \mathrm{c}$. on the territory of the Principality and Voivodship of Mstsislaw', 'Temples mentioned on the territory of the Voivodship of Mstsislaw in the $17^{\text {th }} \mathrm{c}$.', 'Uniate temples on the territory of the Voivodship of Mstsislaw in the $18^{\text {th }}$ c.', 'Catholic temples on the territory of the Voivodship of Mstsislaw', 'Synagogues on the territory of the Voivodship of Mstsislaw in the $18^{\text {th }} \mathrm{c}$.'

57 "Prepared unprofessionally" in the judgement of Viktar Ciemushau: B.H. Темушев, Книга А.А. Метельского о Мстиславском княжестве и воеводстве (http://www.hist-geo.net/index.php? $\mathrm{p}=153 \&$ more $=1 \& \mathrm{c}=1 \&$ th $=1 \& \mathrm{pb}=1$, access: April 4, 2018).

58 Among others, the following tables: 'Dynamics of founding new villages on the territories of old villages of the Starosty of Krychaw at the end of the $17^{\text {th }}-18^{\text {th }}$ c.', 'List of settlements of the Principality of Mstsislaw in the 14-15 $5^{\text {th }}$ c.', 'Settlements of the Voivodship of Mstsislaw which appear in $16^{\text {th }}$ c. sources', 'Settlements of the Voivodship of Mstsislaw which appear in $17^{\text {th }} \mathrm{C}$. sources', 'Settlements of the Voivodship of Mstsislaw which appear in $18^{\text {th }} \mathrm{C}$. sources', 'Temples of the Principality and Voivodships of Mstsislaw mentioned in sources in the 15-16 $6^{\text {th }} \mathrm{c}$.' 'Temples of the Voivodeships of Mstsislaw mentioned in sources in the $17^{\text {th }}$ c.', 'Uniate temples of the Voivodship of Mstsislaw mentioned in sources in the $18^{\text {th }}$ c.', 'Catholic churches of the Voivodship of Mstsislaw'.
} 
serve as an example of how works of this type should look and according to what principles they should be prepared ${ }^{59}$.

Lastly, we should also mention the publication series of the castle museum in Mir devoted to famous families of the Grand Duchy of Lithuania of Ruthenian origin. The maps of land estates have been prepared in the form of appendices to the monographs of the families of Ilinicz $^{60}$ and Drucki Horski ${ }^{61}$. Furthermore, the source text edition of documents from the history of Mir, the castle and the county of Mir is supplemented with a map of the county in the $16-19^{\text {th }}$ century ${ }^{62}$. The person responsible for the preparation of these maps is Dzmitry Vitsko. Other maps of this author include: 'Forest of Naliboki, Dzyerawnaya and Khatava of Karol Stanisław Radziwiłł in $1778^{\prime}$ - as a supplement to the article by Dzmitry Kryvasheyeu about the forest of Naliboki which belonged to princely family Radziwiłł in the $16-18^{\text {th }}$ century (in cooperation with the author of the article $)^{63}$.

To summarise, we can conclude that historical cartography is developing with

59 Here we can also mention some articles by Andrei Miacielski concerning the discussed topics: A.А. Мяцельскі, Воласць Крычава у XIIсярэдзіне XVI стст.: тэрыторыя, адміністрацыйна-гаспадарчы падзел, паселішчы, "Гістарычна-археалагічны зборнік", 15, 2000, р. 81-92 (the period of the Grand Duchy of Lithuania is referred to in the map "Estate of Krychaw in the middle of the $16^{\text {th }}$ c.'); idem, Лучыцкая воласць XV-XVIII стст,, "Весці Акадэміі навук Беларусі. Серыя гуманітарных навук", 4, 2000, p. 59-66 (without map); idem, Мястэчкі Мсціслаускага ваяводства XVI-XVIII стст., "Гістарычна-археалагічны зборнік", 23, 2007, p. 66-81.

60 Р.А. Аляхновіч, С.А. Рыбчонак, А.І. Шаланда, Род Іллінічау у Вялікім Княстве Літоускім у XV-XVI стст., Мiнск 2015 (map by Dzmitry Vitsko and Aliaksiei Shalanda 'Estates of llinicz family in the Grand Duchy of Lithuania $\left.\left(15-16^{\text {th }} \mathrm{c} .\right)^{\prime}\right)$.

61 В.У. Галубовіч, С.А. Рыбчонак, А.І. Шаланда, Князі Друцкія-Горскія у Вялікім Княстве Літоускім у XV-XVIII стст., Мінск 2016 (map by Dzmitry Vitsko “Estates of princely family Drucki Horski in the $15^{\text {th }}$-middle of the $18^{\text {th }} c$. ').

62 Мір Радзівілаў: замак, мястэчка і графсства (1568-1813), склад. А.І. Шаланда, Mip 2017 (map by Dzmitry Vitsko 'County of Mir (16-19 ${ }^{\text {th }}$ c.)').

63 Д. Крывашэеў, Налібоцкая пушча князёу Радзівілаў у XVI-XVIII стст." фармаванне тәрыторы, адміністрацыя і службоўцы, in: Верхняе Панямонне, вып. 1, Мінск 2012, р. 30-50 (map by Dzmitry Vitsko and Dzmitry Kryvasheyeu 'Naliboki, Dzierawnaya and Khatava Forest of Karol Stanisław Radziwitt in 1778'). difficulty in Belarus. In spite of the significant number of prepared and published individual maps and atlases, we are still lacking works in historical geography that would study and justify borders in the period of the Grand Duchy of Lithuania and present the settlement of that period. This is a particularly important task, because this is the most important period, covering over 500 years of the history of Belarus. This is the period when the majority of the present-day cities were founded and the settlement network was established.

Necessary steps in this direction have already been taken by such researchers as Spirydonau, Nasievich, Ciemushau, Miacielski and others; quite a lot of data have been introduced into academic debate concerning the history of borders and population of the Grand Duchy of Lithuania. The most desirable direction of research is currently believed to be the typical disquisition covering the history of a certain administrative unit, i.e. the district from the moment of its creation until its liquidation at the end of the $18^{\text {th }}$ century. Through study of population and borders of specific estates (in particular neighbouring with the border districts), it will be possible to attain this goal. The work which is the closest to this model is the monograph by Miacielski on the Principality and Voivodship of Mstsislaw.

Translated by Paulina Wactawik 


\section{Bibliography}

Ацяхновіч Р.А., Рыбчонак С.А., Шаланда A.I., Род Іиінічаў у Вялікім Княстве Аітоўскім у XV-XVI cmcm., Мінск 2015.

Amлас гісторы Беларусі ад старажкьтнасиі да нашьцх дзён, Мінск 2006.

Amлас гісторы Беларусі ад старажкьтнасиі да нашььх дзён (дадатак да 6-томнай "Энцььклапедьіi zісторыі Беларусі”), аўтар тэкста А.І. Языковіч, склад. Г.Р. Шыкунова, А.У. Языковіч, Мінск 2004.

Варонін В.А., Князь Юрай Аььнгвеневіч Мсиіслаўскі: гістарычны партрэт, Мінск 2010.

Варонін В.А., Рэестр путных баяр Полаукага ваяводства 1585 года, Мінск 2009.

Bялікае Княства Аітоускае: Энщьклапедья, рэд. Г.П. Пашкоў et al., т. 1-3, Мінск 2007-2010.

Вялікі гістарычны атлас Беларусі, т. 1, рэд. В.А. Насевіч, Мінск 2009

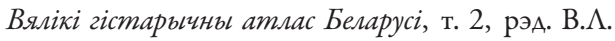
Насевіч, Мінск 2013.

Галубовіч В.У., Рыбчонак С.А., Шаланда А.І., Князі Аруикія-Горскія у Вялікім Княстве Аітоускім y XV-XVIII cmcm., Мінск 2016.

Гістарычны атлас Беларусі, рэд. М. Спірыдонаў, В. Мікалаевіч, П. Казанецкі, т. 1: Беларусь ад старажыьтных часоу да канияа XVIII cm., Варшава-Мінск 2008.

Крикун Н., Административно-территориальное устройство Правобережной Украинь в $X V$ XVIII вв. Границы воеводств в свете источников, Киев 1992.

Крывашэеў А., Налібоцкая пушча князёу Радзівілау у XVI-XVIII стст.: фармаваннетэрыторьі, адміністрацызя $і$ службоуць, іп: Верхняе Панямонне, вып. 1, Мінск 2012, р. 30-50.

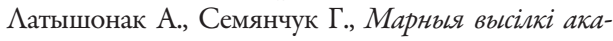
дэмічных гісторьюкау, "Arche", 6, 2010, р. 298322.

Макараў М.А., Ад пасада да магдэбургіi: прававое становішча насельніцтва местау Беларускага Падзвіння ў XIV-nершай палове XVII cm., Мінск 2008.

Мацук А., Барацьба магнацкіх груповак у ВКА (1717-1763), Мінск 2014.

Мір Радзівілаў: замак, мястэчка і графства (15681813), склад. А.І. Шаланда, Мip 2017.

Мянжынскі В., Азярновіч А., Шияхта, іншья землеуласнікі $і$ землеуладальнікі ды іхныля зямельнья ўладанні у Берасиейскім, Камянецкім і Кобрынскім паветах у другой палове $X V$-першай палове XVI cm. (паводле Кнігаў № 12-33 Метрькі BKA), in: Metriciana, т. 3, Мінск 2004, p. 57-196.

Мяцельскі А.А., Воласць Крьчава ў XII-сярэдзіне XVI стот.: тэрыторьци, адміністрацьийна-гаспа- дарчьь падзел, паселішчь, "Гістарычна-археалагічны зборнік”, 15, 2000, р. 81-92.

Мяцельскі А.А., Аучьикая воласиь XV-XVIII cmст., "Весці Акадэміі навук Беларусі. Серыя гуманітарных навук”, 4, 2000, p. 59-66.

Мяцельскі А.А., Мсціглаускае княства і ваяводства $\check{y}$ XII-XVIII cmcm., Мінск 2010 (2-е выА. Мінск, 2014).

Мяцельскі А.А., Мястэчкі Мсиіслаускага ваяводсmва XVI-XVIII cmcm., "Гістарычна-археалагічны зборнік”, 23, 2007, p. 66-81.

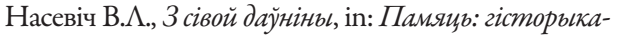
-дакументальная хроніка Гораукага раёна, рэл. А.А. Крывянкоў et al., Мінск 1996, p. 26-41.

Насевіч В.А., Аукомль і Аукомльскал воласць, "Гістарычна-археалагічны зборнік”, 4, 1994, р. 161186.

Насевіч В.А., Менскае княства і воласиь у XIIXV cm., "Беларуская даўніна", 2, 2015, р. 50-63.

Насевіч В.А., Некалькі разважанняу з нагодьь рэиэнзіі Алега Матьионка і Генадзя Семяниука, "Arche", 6, 2010, p. 323-329.

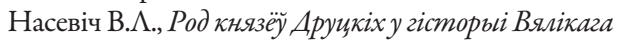
Kняства Aimoy̆скага (XIV-XVI cmcm.), in: Cmaронкі гісторы Бе Беларуі, рэд: М.П. Касцюк еt al., Мінск 1992, р. 83-104.

Насевіч В.А., У складзе Вялікага княства Аітоўскагa, in: Памлиь: гісторька-дакументальная хроніка Аунінецкага раёна, укмад. Т.В. Канапацкая, Мінск 1995 , р. 29-45.

Насевіч В.А., У складзе Полацкага княства. У складзе Вялікага княства Аітоускага, in: Памячь: гісторька-дакументальная хроніка Крупскага раёна, склад. і рэд. А.М. Хомчанка, Мінск 1999, p. 37-64.

Насевіч В.А., Феадальньц маёнткі $і$ іх уладальнікі, in: Памяць: гісторька-дакументальная хроніка Круглянскага раёна, рэА. Г.П. Пашкоў et al., Мінск 1996, р. 92-119.

Нацьцянальны атлас Беларусі, рэд. У.М. Мясніковіч et al., Мінск 2002.

Памяць: гісторька-дакументальная хроніка Мінскага раёна, рэд. Г.П. Пашкоў et al., Мінск 1998.

Памяць: гісторька-дакументальная хроніка Навагрудскага раёна, рэл. М.П. Касцюк et al., Мінск 1996.

Перапіс войска Вялікага княства Аітоўскага 1528 года, рэд. А.І. Груша, М.Ф. Спірыдонаў, М.А. Вайтовіч, Мінск 2003.

Полацкая рэвізія 1552 года, уклаў В. Варонін, Мінск 2011.

Радаман А.А., Аа праблемь вызначэння мяжы паміж Новагародскім і Пінскім паветамі Вялікага 
княства Аітоўскага, Рускага і Жамойцкага ў другой палове XVI cm., in: Памяць стагоддзяу на карие Айчьнь: зборнік навуковых прачу у гонар 70-годдзя Міхаіла Фёдаравіча Спірьцонава, Мінск 2007, p. 73-89.

Русккая историческая библиотека, т. 30, Юрьев 1914.

Спиридонов М.Ф., Беларусь ХVI в. на исторических картах, in: Гістарызяграфія гісторыі Беларусі: стан і перспектывы развічия, рэд. М. Касцюк et al., Мінск 2000, p. 90-94.

Спиридонов М.Ф., Закрепощение крестьянства Бегаруси (XV-XVIвв.), Минск 1993.

Спиридонов М.Ф., Заславль в ХVI в., Минск 1998.

Спиридонов М.Ф., Источники о реформе административно-территориального деления Великого княжкества Аитовского 1565 г. в зарубежнььх архивах, in: Замежная архіўная беларусіка, рэд. У.М. Міхнюк еt al., Мінск 1998.

Спиридонов М.Ф., Метрика Великого княжкетва Аитовского как источник по истории поселении, in: Lietuvos Metrika: 1991-1996 metu tyrinejimai, sud. Z. Kiaupa, A. Urbanavičius, Vilnius 1998, p. 115-133.

Спиридонов М.Ф., Населенные пункты Менского повета в 1567 г., in: Актуальныц пытанні выьвучэння $і$ выцданя Метрькі Вялікага Княства Аіmоўскага, рэл. С.П. Віцязь еt al., Мінск 2005, p. 159-190.

Спірыдонаў М.Ф., Завяриэнне фарміравання Пінскага павета ў 1566 г., "Весці НАН Бекарусі. Серыя гуманітарных навук”, 4, 1998, p. 42-50.

Спірыдонаў М.Ф., Першая ардьнацьљя ў Беларусі, “Гістарычна-археалагічнызборнік”, 8, 1996, р. 198 216.

Темушев B.H., Автобиография (http://www.hist-geo. net/index.php?blog=1\&paged=9, access: April 4, 2018).

Темушев В.Н., Гомельскал земия в конце $X V$-первой половине XVI в. Территориальнье трансформачии в пограничном регионе, Москва 2009.

Темушев В.Н., Западнал гранииа Великого кияжества Московского к 1380 г., in: Куликовскал битва в истории России, реА. А.Н. Наумов, Тула 2006, p. 82-109.

Темушев В.Н., $К$ вопросу о московско-литовской гранище в XV в. (Волости Чагоша и Болонеск), in: Матэрыцлы па археалогіi Беларусі, вып. 15, Мінск 2008, p. 186-193.

Темушев В.Н., Книга А.А. Метельского о Мстиславском княжестве и воеводстве (http://www.histgeo.net $/$ index.php? $=153 \&$ more $=1 \& \mathrm{c}=1 \& \mathrm{tb}=$ $1 \& \mathrm{pb}=1$, access: April 4, 2018).

Темушев В.Н., Кричевский участок митовско-московской границьь в XVI в., in: Studia historica
Europae Orientalis = Исследования по истории Восточной Европьи, вып. 3, Минск 2010, р. 135165.

Темушев В.Н., Аитовско-тверская граница (вторая половина XIV-начало XVI в.), "Вестник ТвГУ. Сер. История”, 4, 2007, p. 87-97.

Темушев В.Н., На восточной границе Великого княжества Аитовского. Середина XIV-первал половина ХVI в., Тула 2016.

Темушев В.Н., Первая московско-литовская пограничная война, 1486-1494, Москва 2013.

Темушев В.Н., Пограничные города Великого княкества Аитовского: Aмитровеи в XV в., in: Studia historica Europae Orientalis = Исследования nо истории Восточной Европь,, вып. 2, Минск 2009, p. 44-122.

Темушев В.Н., Представления о территории и границах Верхнеокских княжеств в работах иследователей, in: Верхнее Подонье: Природа. Археомогия. История, т. 2: История, реА. А.Н. Наумов, Тула 2007, р. 257-277.

Темушев B.Н., Развитие исторической географии, in: Институт истории Национальной академии наук Беларуси (1929-2009 г2.), рук. А.А. Коваленя et al., Минск 2009, р. 557-561.

Темушев В.Н., Ржевский участок митовско-московской границь в конце XIV-начале XVI в., in: $M a$ тэрьциь па археалогіi Беларусі, вып. 14, Мінск 2007, p. 241-250.

Темушев В.Н., Сведения о московско-литовском пограничье в посольских книгах времени Ивана III, in: Труды кафедры истории России с древнейших времен до XX века, отв. реА. А.Ю. Аворниченко, Санкт-Петербург 2006, р. 294-306.

Темушев В.Н., Спорньц участки митовско-московской границы XVI в., in: Матэрылиы па археалогіi Беларусі, вып. 20, Мінск 2011, р. 112-118.

Темушев В.Н., Феномен московско-литовского порубежья XV века, in: Вялікае княства Аітоускае і яго суседзі ў XIV-XV cmст., уклад.: A.I. Груша, С.В. Марозава, Мінск 2011, р. 199-206.

Франциск Скорина и его время: энциклопедический справочник, Минск 1990.

Цемушаў B.M., "Вайна падчас міру”. Першаs naмежная вайна ВКА з Масквою (1486-1494), “Бенарускі гістарычны агляА”, 15 (1-2), 2008, p. 5-48.

Цемушаў B.M., "Вялікі гістарычны атлас Беларусі" у крывымм люстэрку рэиэнзіі (Адказ на рэиэнзію Алега Аатьционка і Генадзя Семянчука), "Arche", 6, 2010, p. 330-343.

Цемушаў B.М., Гістарычныья атласы і стан развіция сучаснай гістарычнай геаграфіi ў Беларусі, "Гісторыка-археалагічны зборнік", 25, 2010 , p. 200-203. 
Цемушаў B.М., Мажайскал зямля: яе тэрытторыя і межы, "Беларускі гістарычны часопіс", 1, 2002, p. 23-28.

Цемушаў B.М., На ўсходняй мяжьь Вялікага княства

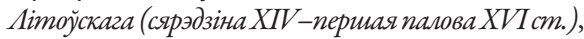
Смаленск 2014.

Цемушаў B.М., Праблемьь развічия гістарьинай геаграфіi Беларусі, "Бемарускі гістарычны агмяд", 10 (1-2), 2003, p. 228-255.

\section{Summary}

In Belarus, the historical geography is a relatively new and slowly developing discipline. It is widely acknowledged that its founder was Mikhail Spirydonau as he was the author of the first, published in 1993, detailed map of the Grand Duchy of Lithuania after signing the Union of Lublin, as well as the maps of particular districts. It was he who laid the foundations of the discipline and his maps are at the core of entire body of the geohistorical knowledge on The Grand Duchy of Lithuania.

In the following years, the researchers Viachaslau Nasievich, Viktar Ciemushau, Andrei Miacielski and others had introduced into the scientific literature a great amount of data on the history of borders and population of the GDL, though the article only lists those works which contain maps or other cartographic editions. A number of historical atlases were also published, the most important of which is the 'Great Historical Atlas of Belarus' edited by Nasievich. The eastern border of the Grand Duchy of Lithuania in the
Цемушаў B.М., Тросненскал бітва і паўднёва-заходняq мажа Вялікага Княствва Маскоусказа у 1368 г., “Бемарускі гістарычны агмяА”, 13 (2), 2006, р. 135176.

Энщъцклапедъц гісторыі Беларусі, т. 1-6, Мінск 1993-2003.

Błaszczyk G., Geografia historyczna Wielkiego Księstwa Litewskiego. Stan i perspektyuy badań, Poznań 2007. $14^{\text {th }}$ until the first half of the $16^{\text {th }}$ century was the subject of studies by Ciemushau. Currently, despite a great number of elaborated and published maps and atlases, the publications still lack works on historical geography, which would tackle and justify the administrative borders of the GDL and which would depict its settlement network. Such works present a great challenge, as this most important period covers over half of the millennium of Belarusian history.

A typical disquisition on the history of a particular administrative unit, which is a district, since it origins until its end in the $18^{\text {th }}$ century is seen as the most desirable scientific approach to the topic. It can be achieved by studying the population and the borders of particular estates (the ones at the borders of the neighbouring districts in particular). The work which is the closest to this model is the monograph by Miacielski on the Principality and Voivodship of the Principality and Voivodship of Mstsislaw.

Keywords: historical map, administrative border, district, population, settlements, historical atlas

Dzmitry Vitsko - the editor of "Arche" magazine (Minsk, Belarus). His scientific interests include the military and political history of the end of the $17^{\text {th }}$ and the beginnings of the $18^{\text {th }}$ century as well as the historical geography of Grand Duchy of Lithuania (e-mail: zmiejavik@gmail.com) 